him, one son having been killed in the First World War.

He was keen on any natural science subject which he took up: chemistry, botany, spiders and, above all, ornithology. He loved birds from boyhood, and he was very familiar with the habits and songs of Indian birds.

Mr. Osmaston's life in the jungle inevitably brought a large share of excitement and adventure in the form of encounters with dangerous wild animals, but one of the most exciting occurred within three months of his arrival in India, and is well worth recording again. He was posted to the district of Jaunsar in the hills, where there had been a man-eating tigress taking a toll of human life for ten years. Mr. Osmaston, then aged twenty-one, and a forest student named Mr. Hansard, decided to try to stalk the tigress in the heat of the day, when, they felt sure, she would be lying up in some secluded place. They went cautiously down a steep ravine which was covered with thick scrub, one of them on each side of the steep banks bordering the small stream. They had not been going for more than five minutes when Mr. Osmaston heard a scuffle and a terrible noise of growling, mixed with cries and groans above him. The tigress had stalked the stalkers, and had pounced on Mr. Hansard from behind. Mr. Osmaston, who had never before seen a tiger outside a zoo, had to risk a shot at the tigress while she was mauling $\mathrm{Mr}$. Hansard. The shot made the tigress let go her hold, and the second barrel discharged at her as she came beadlong down the bank towards him finished her off. Mr. Hansard's life was saved, though he had been badly mauled, and the scourge of the countryside was dead. Mr. Osmaston had achieved what many a famous hunter had tried to do during the previous ten years.

His adventures included an encounter on foot with the rogue elephant which had caused the death of Mrs. Anson; an exciting escape from drowning when shooting some rapids in a canoe; navigating a small launch by compass and map without previous experience, in order to find a certain uninhabited island in the Andamans which was reputed to be the only habitat of some very rare hornbills. This adventure included the onset of a storm resulting in the loss of the landing boat while the party was ashore, which necessitated a dangerous swim in rough water infested with sharks, back to the launch, which was anchored in deeper water.

These few incidents serve to show Mr. Osmaston's adventurous spirit. He was abstemious and thrifty all his life, and his disregard for personal comfort and safety took him to many strange and interesting places, and he had very wide knowledge of all things to do with life in the jungle.

After retirement he participated in two strenuous expeditions in pursuit of further knowledge about birds, the first to Ladakh at very high altitudes, and the second in Africa. Both these expeditions were undertaken in the company of his good friend Admiral Lynes, another keen ornithologist.

By his death, at the age of ninety-three, the world has lost a very courteous, charming and adventurous personality.

\section{Dr. T. P. Colclough, C.B.E.}

Tom Colclough, as he was known to ferrous metallurgists, who died on September 22, aged seventy-six, was one of those rare personalities who commanded respect in both industry and research. $\mathrm{He}$ was educated at the Universities of Manchester and Sheffield, and awarded the D.Se. of Manchester and the D.Met. at Sheffield. He entered the BrownFirth Research Laboratories in 1916 under W. H. Hatfield and in 1920 became chief chemist at Park Gate Iron and Steel Co., Ltd. He was appointed in turn chief metallurgist, open-hearth manager and technical officer. In 1929 he became technical director of H. A. Brassert and Co. and was directly concermed with subsequent developments at Corby, Ebbw Vale and other steel works. His capacity for sensing the direction of developments in iron and steel contributed to an international reputation covering Germany, Austria. Turkey, China and New Zealand.

During the Second World War he was technical adviser to the Iron and Steel Control of the Ministry of Supply, and was appointed C.B.E. for his services in 1947. In 1945 he continued in this field as technical adviser to the British Iron and Steel Federation, which post he held at the time of his death. His post-war travel ranged from work with the Control Commission in Germany at the end of the War, to advise the Durgapur works in India and the R.I.S.C.O. works in Southern Rhodesia. He was the leader of British Iron and Steel Federation missions to the U.S.S.R., Poland and Yugoslavia.

Research was not forgotten amid this industrial activity, for he participated in the work of the British Iron and Steel Research Association, and from 1950 served as a member of its Council. He was awarded the Bessemer Gold Medal of the Iron and Steel Institute in 1954, and elected an honorary vicepresident of that Institute in May 1960.

Until recently he delivered an annual lecture in the Department of Metallurgy at Manchester, which was always received with eager concentration by the students. He had the power to hold the attention and stimulate his audience which scarcely changed with advancing years. In these days of specialization, his combination of forward thinking with the necessary restrictions of practice was as welcome as it was unusual.

C. R. TotTle

\section{Dr. E. McKenzie-Taylor, C.I.E., M.B.E.}

Dr. E. McKrnzin-TAYLOR died at his home at Basildon on October 17. He was a North-country man and received his early training at Armstrong College, Newcastle upon Tyne, before the First World War; for a short time he was a demonstrator in agricultural chemistry there. His first appointment elsewhere was as lecturer in agricultural science at the Harper Adams Agricultural College. From there he moved to the East Anglian Institute of Agriculture at Chelmsford, where he became head of the Department of Agrieultural Chemistry, and as such was concerned primarily with analytical work connected with agricultural problems.

After service in the Royal Artillery during the First World War, he returned to Chelmsford until 1921, when he was appointed senior chemist to the Cotton Research Board of the Egyptian Ministry of Agriculture. Here, with A. C. Burns, he carried out important work on the daily and seasonal changes in soil temperature and on other factors influencing the yield of cotton. In particular, they investigated the steady decrease which had been experienced in the yield of cotton in Egypt during the previous quarter 